\title{
Variability in plankton community structure, metabolism, and vertical carbon fluxes along an upwelling filament (Cape Juby, NW Africa)
}

Javier Arístegui $^{1^{*}}$, Eric D. Barton ${ }^{2}$, Paul Tett ${ }^{3}$, María F. Montero ${ }^{1}$, Mercedes García-Muñoz ${ }^{1}$, Gotzon Basterretxea ${ }^{4}$, Anne-Sophie Cussatlegras ${ }^{5}$, Alicia Ojeda ${ }^{6}$, Demetrio de Armas ${ }^{7}$,

${ }^{1}$ Facultad de Ciencias del Mar, Universidad de Las Palmas de Gran Canaria, Spain

${ }^{2}$ School of Ocean Sciences, University of Wales, Bangor, UK

${ }^{3}$ School of Life Sciences, Napier University, Edimburgh, UK ${ }^{4}$ IMEDEA (CSIC-UIB), Esporles, Balears, Spain

${ }^{5}$ Centre d'Océanologie de Marseille, Université de la Méditerranée, France

${ }^{6}$ Instituto Canario de Ciencias Marinas, Gran Canaria, Spain

${ }^{7}$ Instituto Español de Oceanografía, Tenerife, Spain

*jaristegui@dbio.ulpgc.es 


\section{Abstract}

The variability in dissolved and particulate organic matter, plankton biomass, community structure and metabolism, and vertical carbon fluxes were studied at 4 stations (D1-D4), placed along a coastal-offshore gradient of an upwelling filament developed near Cape Juby (NW Africa). The filament was revealed as a complex and variable system in terms of its hydrological structure and distribution of biological properties. An offshore shift from large to small phytoplankton cells, as well as from higher to lower autotrophic biomass, was not paralleled by a similar gradient in particulate (POC) or dissolved (DOC) organic carbon. Rather, stations in the central part of the filament (D2 and D3) presented the highest organic matter concentrations. Autotrophic carbon $\left(\mathrm{POC}_{\mathrm{Chl}}\right.$ ) accounted for 53\% (onshore station, D1) to 27\% (offshore station, D4) of total POC (assuming a carbon to chlorophyll ratio of 50), from which nano- and pico-phytoplankton biomasses $\left(\mathrm{POC}_{\mathrm{A}<10 \mu}\right)$ represented $14 \%$ (D1) to $79 \%$ (D4) of $\mathrm{POC}_{\mathrm{Chl}}$. The biomass of small hetrotrophs $\left(\mathrm{POC}_{\mathrm{H}<10 \mu}\right)$ was equivalent to POC $_{\mathrm{A}<10 \mu}$, except at D1, where small autotrophs were less abundant. Dark community respiration $\left(\mathrm{R}_{\mathrm{d}}\right)$ in the euphotic zone was in general high, almost equivalent to gross production $\left(\mathrm{P}_{\mathrm{g}}\right)$, but decreasing offshore (D1-D4, from 108 to $\left.41 \mathrm{mmol} \mathrm{C} \mathrm{m}^{-2} \mathrm{~d}^{-1}\right)$. POC sedimentation rates $\left(\mathrm{POC}_{\text {sed }}\right.$ ) below the euphotic zone ranged from 17 to $6 \mathrm{mmol} \mathrm{C} \mathrm{m}^{-2}$ $\mathrm{d}^{-1}$. Only at D4 was a positive carbon balance observed: $\mathrm{P}_{\mathrm{g}}-\left(\mathrm{R}_{\mathrm{d}}+\mathrm{POC}_{\mathrm{sed}}\right)=42 \mathrm{mmol} \mathrm{C}$ $\mathrm{m}^{-2} \mathrm{~d}^{-1}$. Compared to other filament studies from the NE Atlantic coast, the Cape Juby filament presented lower sedimentation rates and higher respiration rates with respect to gross production. We suggest that this is caused by the recirculation of the filament water, induced by the presence of an associated cyclonic eddy, acting as a trapping mechanism for organic matter. The export capacity of the Cape Juby filament therefore would be constrained to the frequency of the interactions of the filament with islandinduced eddies.

Keywords: Carbon fluxes, Plankton metabolism, Plankton community structure, Upwelling filament, Cape Juby, NW Africa 


\section{Contents}

1. Introduction

2. Material and methods

2.1. Region of study, sampling strategy and hydrological measurements

2.2. Analysis of water samples

2.3. Plankton cell counts

2.4. Plankton conversion to biomass

2.5. Plankton metabolism experiments

2.6. Sediment traps

3. Results

3.1. Water column structure, nutrient salts and organic matter

3.2. Changes in plankton community structure and biomass

3.3. Plankton metabolism and vertical carbon fluxes

4. Discussion

Acknowledgements

References

\section{Introduction}

Filament structures are ubiquitous features in coastal upwelling systems (e.g. Brink \& Cowles, 1991; Barton et al., 1998; Joint et al., 2001). Their origin may be attributed to a variety of causes, but generally they are associated with offshore cyclonic and anticyclonic eddies that may enhance or reduce water exchange between the eutrophic upwelled waters and the oligotrophic open ocean. The offshore flow of coastal waters channelled along filaments may be, at times and at regional scale, considerably more significant than the Ekman flow (Barton et al., 1998). Hence it is plausible that filaments contribute largely to the export of organic matter from coastal regions to the open sea.

However, limited knowledge of the dynamics and variability of upwelling filaments, renders it difficult to draw any global conclusions on their biological effects. Some recent work in upwelling regions from the NE Atlantic coast (Alvárez-Salgado et al., 
2001; García-Muñoz et al., 2004) gives evidence that filaments may transport a considerable fraction of coastal primary production, either in dissolved or particulate form, even during low upwelling intensity. The nature and magnitude of the organic matter transported will depend largely on the size structure of plankton communities, as well as on the state of mineralization of the organic matter exported. Moderate to intense upwelling episodes favour the development of large plankton cells that are readily exported offshore (Head et al., 1996; Joint et al., 2001; Basterretxea \& Arístegui 2000). On the contrary, weak and sporadic upwelling pulses lead to the development of plankton communities composed of small cells (García-Muñoz et al., 2003), with higher excretion rates of dissolved material (Nagata, 2000). Moreover, weak offshore flows along filaments, as result of low wind intensity, favour higher mineralization rates along the filament path. Since coastal upwelling systems fluctuate under variable wind pulses, shifts between plankton communities composed of large and small cells are presumably frequent, which affects the potential of a coastal upwelling system to export biogenic carbon offshore.

The role of upwelling filaments in the shelf to ocean transport of organic matter will depend also on eddy-filament interactions, which frequently occur on ocean margins (e.g. Brink \& Cowles 1991; Barton et al., 1998). Oceanic eddies may entrain filament waters with higher content of organic matter, enhancing the shelf-ocean exchange (Arístegui et al., 1997). Filaments may return to the continental shelf part of the water upwelled and expelled from the coast by means of eddy-associated circulation. This recirculation decreases the impact of filaments on the offshore transport of organic matter (e.g. Basterretxea \& Arístegui, 2000).

In this paper, we report the biological variability along a recurrent filament studied during the FAX cruise, carried out in the Canary Islands region in August, 1999, on board the BIO Hespérides. The filament stretched offshore between Cape Juby and Cape Bojador (NW Africa upwelling system) as far as Gran Canaria Island, but recirculated back, forced by the cyclonic rotation of an associated offshore eddy (see Barton et al., 2004). We have analysed the changes in plankton community structure, the distribution of organic matter, the microbial community metabolism, and the vertical carbon fluxes at 4 stations placed along the coastal-offshore extension of the filament. The results of our study are compared with published filament studies in order to 
understand the variability of the biological effects of upwelling filaments. Our study highlights the importance of the eddy-filament interactions in determining the nature and magnitude of the biological properties transported to the open ocean by filaments.

\section{Material and methods}

\subsection{Region of study, sampling strategy and hydrological measurements}

The surveyed filament system evolved from a single to a double-branch structure during the two weeks of the study (Fig. 1a,b; see Barton et al., 2004, for a detailed description of the hydrography and filament evolution). The cause of the variation was the interaction of the filament with an anticyclonic eddy (A7) generated in the lee of Fuerteventura Island. The evolution of the surface signature of the filament was tracked by AVHRR imagery throughout the sampling, which allowed the selection of four (D1D4) 24h station positions. Chronologically, the first sampled station (D2; 11 August, 1999) was placed near the origin of the southern filament (F1), beyond the continental shelf; D1 (17 August) was positioned in the shallow shelf waters $(<100 \mathrm{~m})$ of the coastal upwelling. On 12 August, the interaction of F1 with eddy A7 enhanced the development of a second filament (F2) at a more northern position. The two filaments merged at station D3 (22 August) into a single structure, some $100 \mathrm{~km}$ offshore. Station D4 (24 August) was placed in oceanic waters near Gran Canaria Island, where the filament turned southwards, induced by the rotation of cyclonic eddy C7, a recurrent feature trapped in the trough between the inner islands and the African shelf (Barton et al. 1998). At the end of the cruise, an unknown amount of filament water was entrained by an anticyclonic eddy (A6) developing at the lee of Gran Canaria.

At each station, temperature, salinity, fluorescence and light transmission were recorded down to 200 m (when possible) by means of a SeaBird 9-11+ CTD, plus Sea-Tech fluorometer and transmissometer, mounted on a General Oceanics rosette sampler equipped with 24 12-l Niskin bottles. Attenuation of spectral irradiance (between 400 and $700 \mathrm{~nm}$ ) in the water column was measured with a LiCor 1800 submersible spectroradiometer. Photosynthetically active radiation (PAR) was calculated by summing the spectral irradiance values. Samples for inorganic nutrients (except for D2), chlorophyll a (Chl), particulate organic carbon and nitrogen (POC, PON), dissolved 
organic carbon (DOC), proteins (Pt), and plankton abundances were collected at 7 to 9 depths; from surface to 50-200 m. Additionally, samples for plankton metabolism experiments were obtained at 6 depths from the upper $50 \mathrm{~m}$ or $100 \mathrm{~m}$. They were incubated in drifting arrays, together with sediment traps deployed below the euphotic zone (see below).

The time between the $\mathrm{D}$ stations was used to perform dense sampling grids (1 mile separation between stations) across the filament branches, with the aim of monitoring the short scale physical, and bio-chemical variability of the filament system (data not shown; see Barton et al., 2004).

\subsection{Analysis of water samples}

Seawater samples for the analysis of inorganic nutrients were stored in polyethylene bottles and kept frozen at $-20^{\circ} \mathrm{C}$ during the cruise for analysis in the shore laboratory. Nitrate, nitrite, phosphate and silicate were analysed colorimetrically by continuous flow analysis, by means of a Technicon-Bran Luebbe AAII autoanalyzer, following the JGOFS recommendations (UNESCO, 1994)

Chl was estimated fluorometrically by means of a Turner Designs bench fluorometer, previously calibrated with pure chlorophyll a (Sigma Co.), according to Holm-Hansen et al. (1965). Seawater samples (500 ml) were filtered through Whatman GF/F fibre filters. Pigments were extracted on board in cold acetone (90\% v/v) for $24 \mathrm{~h}$. Extracted Chl samples were used to calibrate the voltage readings of the submersible fluorometer (Sea-Tech 57S) linked to the CTD unit.

Proteins (Pt) were determined according to the Peterson's modification (Peterson, 1983) of the Lowry et al. (1951) method; using a protein assay kit provided by Sigma Co. Water samples (5 l) were concentrated on GF/F filters. Pt were extracted by grinding the filters with Lowry reagent directly and diluting with water afterwards. Sodium dodecylsulfate included in the Lowry reagent facilitates the dissolution of relatively insoluble lipoproteins. Replicate assays were run for each sample. BSA (Bovine Serum Albumin) standards with Pt concentrations between 4 and $400 \mu \mathrm{g} / \mathrm{l}$ were run at the same time to obtain a calibration curve. The average precision obtained in triplicate samples 
was $\mathrm{CV}=3.1 \%$.

Samples (2 l) for POC and PON were filtered through pre-combusted ( $450^{\circ} \mathrm{C}, 12$ hours) $25 \mathrm{~mm}$ Whatman GF/F filters. The filters were wrapped in pre-combusted aluminium foil and frozen at $-20^{\circ} \mathrm{C}$ until processed (a few weeks later). In the laboratory the filters were thawed and dried overnight at $65^{\circ} \mathrm{C}$ and packed in pre-combusted nickel sleeves. The carbon analyses were performed on a Perkin Elmer-2400 CHN elemental analyzer, according to the JGOFS protocol (UNESCO, 1994).

Water samples $(10 \mathrm{ml})$ for the analysis of total organic carbon (TOC) were dispensed directly from the Niskin bottles into pre-combusted $\left(500^{\circ} \mathrm{C}, 12\right.$ hours) glass ampoules. The samples were immediately acidified with $50 \mu \mathrm{l}$ of $50 \% \mathrm{H}_{3} \mathrm{PO}_{4}$, sealed, and stored at $2-4^{\circ} \mathrm{C}$ until analyzed (Sharp \& Peltzer, 1993). TOC concentrations were measured using a Shimadzu TOC-5000 analyzer. At the beginning of each analysis run, the sample was sparged with $\mathrm{CO}_{2}$-free air for several minutes to remove the inorganic carbon. The sample was then injected (3 replicates of $100 \mu$ ) into a quartz tube with a platinum catalyst, and combusted at $680^{\circ} \mathrm{C}$. TOC concentrations were determined from standard curves (30 to $200 \mu \mathrm{M}$ C) of potassium hydrogen phthalate produced every day. TOC reference material prepared in the laboratory of Jonathan H. Sharp (Univ. of Delaware) was analyzed every day to check for the accuracy and precision of our instrument. We obtained an average concentration of $44.5 \pm 2.7 \mu \mathrm{M} \mathrm{C}(\mathrm{n}=31)$ for the Deep Ocean reference material (Sargasso Sea deep water, $2600 \mathrm{~m})$ and $0.21 \pm 0.53 \mu \mathrm{M} \mathrm{C}(\mathrm{n}=31)$ for the Blank reference material, whose nominal values were $44.0 \pm 2.7 \mu \mathrm{M} \mathrm{C}$ and $0.0 \pm 1.5$ $\mu \mathrm{M} C$ respectively. DOC was finally computed by subtracting POC from TOC.

\subsection{Plankton cell counts}

Large phytoplankton (>10 $\mu \mathrm{m})$ and ciliates were observed and enumerated by inverted microscopy, at 400x magnification. Samples (125 ml) were fixed and preserved in a 1\% final concentration of acidic Lugol solution, and settled in Uthermöl chambers for $48 \mathrm{~h}$.

Seawater samples (20 ml) for enumeration of autotrophic (NAF) and heterotrophic (NHF) nano-flagellates were preserved following Haas (1982). Immediately after collection the sample was fixed with glutaraldehyde ( $0.3 \%$ final concentration). After 
$30 \mathrm{~min}$, a $30 \mathrm{ml}$ sub-sample was placed into the filtration tower and fixed with proflavine (6.6 $\mathrm{mg} \mathrm{ml}^{-1}$ final concentration) for 3-5 min. The stained sample was later filtered through a $0.2 \mu \mathrm{m}$ black polycarbonate, membrane filter, lying over a Whatman GF/C backing filter, and finally mounted on a microscope slide with low-fluorescence paraffin oil. Flagellates were counted using epifluorescence microscopy. NAF were distinguished from NHF by their chloroplasts, which emitted red fluorescence when observed under blue light (excitation filter BP 450-490, chromatic divisor FT 510, suppressor filter LP 520). At least 50 cells or 20 fields were counted at a magnification of $\mathrm{x} 1000$.

Heterotrophic bacteria (HB), small photosynthetic eukaryotic cells (picoeukaryotes, PE), and Prochlorococcus (Pro) and Synechococcus (Syn) type cyanobacteria, were counted by flow cytometry, using a FACScalibur (Becton \& Dickinson) instrument. Samples (4 ml) were fixed with $2 \%$ final concentration of formaldehyde, incubated for $15-30$ minutes at $4^{\circ} \mathrm{C}$ and then stored frozen in liquid nitrogen until analyzed. To count HB, 200 $\mu$ l was stained with a DMS-diluted SYTO-13 (Molecular Probes Inc.) stock $(10: 1)$ at $2.5 \mu \mathrm{M}$ final concentration. Bacteria were identified by their signatures in a plot of side scatter (SSC) versus green fluorescence (FL1). High DNA (H-DNA) bacteria and low DNA (L-DNA) bacteria were separated in the scatter plot (Gasol et al., 1999). The identification of small phytoplankton groups (Pro, Syn and PE), was based on interactive analysis of multiple bivariate scatter plots of side scatter, red fluorescence and orange fluorescence. Samples were run at low speed for HB and at medium or high speed for phytoplankton, until 10000 events were acquired. A suspension of yellowgreen $1 \mu \mathrm{m}$ latex beads $\left(\sim 10^{5}\right.$ beads $\mathrm{ml}^{-1}$ for phytoplankton and $\sim 10^{6}$ beads $\mathrm{ml}^{-1}$ for $\mathrm{HB}$ ) was added as an internal standard (Polysciences, Inc.). Cells abundances were calculated from bead concentrations. The bead solution was checked daily through epifluorescence microscopy counting.

\subsection{Plankton conversion to biomass}

The autotrophic biomass was calculated both for the whole autotrophic community, by deriving it from chlorophyll a ( $\left.\mathrm{POC}_{\mathrm{Chl}}\right)$, and for the pico and nanoplankton components $\left(\mathrm{POC}_{\mathrm{A}<10 \mu}\right)$, computed as the sum of the Syn, Pro, PE and NAF biomasses. The biomass of small heterotrophs $\left(\mathrm{POC}_{\mathrm{H}<10 \mu}\right)$ was obtained by summing the $\mathrm{HB}$ and NHF biomass. 
Large phytoplankton cells and ciliates were not converted to biomass, since no biovolume measurements were performed.

Total autotrophic biomass was derived from chlorophyll concentrations by assuming a carbon to chlorophyll conversion factor (C/Chl) of 50. A similar factor has been widely used by many authors (e.g Li et al., 1992; Gasol et al., 1997; Bode et al., 2001), although it probably represents a minimum value, since the ratio may be close to 100 in oligotrophic open-ocean systems (Welschmeyer \& Lorenzen, 1984; Hewes et al., 1990; Verity et al., 1996; Buck et al., 1996).

HB abundances were converted to biomass using a factor of $20 \mathrm{fgC} \mathrm{cell}^{-1}$ (Lee \& Fuhrman, 1987; Cho \& Azam, 1990; Bode et al., 2001). Prochlorococcus cell numbers were converted to biomass assuming a mean biovolume of $0.1 \mu^{3}$ cell $^{-1}$ (Sieracki et al.,

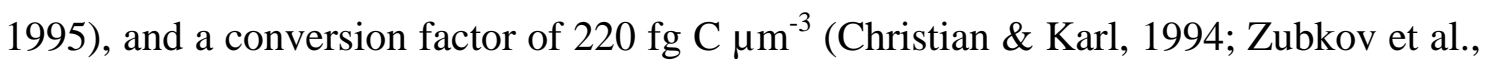
2000). Synechococcus cell numbers were converted to biomass by using a conversion factor of $250 \mathrm{fg} \mathrm{C}^{-1} \mathrm{cell}^{-1}$ (Kana \& Glibert, 1987; Li et al., 1992). The latter factor should, however, be interpreted as merely an approximation, since as Sieracki et al. (1995) observed it depends on the size of the cells, which increases with depth through the water column. PE abundances were transformed to biomass using a conversion factor of 2100 fg C cell ${ }^{-1}$ (Campbell et al., 1994). NAF and NHF numbers were converted to biomass assuming a mean biovolume of $20 \mu^{3}$ cell $^{-1}$ for NAF, and of $10 \mu^{3}$ cell $^{-1}$ for NHF (values estimated for North Atlantic flagellates; J.M. Gasol com. pers.), and a conversion factor of $220 \mathrm{fg} \mathrm{C} \mu^{-3}$ (Børsheim \& Bratbak, 1987).

\subsection{Plankton metabolism experiments}

Gross primary production $\left(\mathrm{P}_{\mathrm{g}}\right)$, net community production $\left(\mathrm{P}_{\mathrm{n}}\right)$, and dark community respiration $\left(R_{d}\right)$ were determined by oxygen evolution inside borosilicate bottles. Water samples were carefully siphoned using a silicone tube into 4 to 5 replicate "time-zero", dark and light $125 \mathrm{ml-BOD}$ bottles. Light bottles were placed in drifting arrays and incubated in situ for 24 hours. Dark bottles were kept in temperature-controlled water baths $\left( \pm 0.1^{\circ} \mathrm{C}\right)$ at in situ temperature for $24 \mathrm{~h}$. $\mathrm{R}_{\mathrm{d}}$ was estimated from the difference in oxygen concentration between the time-zero and dark bottles. On a daily $\mathrm{P}_{\mathrm{n}}$ basis was estimated as the difference between the light and time-zero bottles, by assuming that 
respiration in dark and light were equal. $\mathrm{P}_{\mathrm{g}}$ was calculated as the sum of $\mathrm{P}_{\mathrm{n}}$ and $\mathrm{R}_{\mathrm{d}}$.

Dissolved oxygen was measured by the Winkler technique, following the recommendations of Carrit \& Carpenter (1966), Bryan et al. (1976) and Grasshoff et al. (1983). The entire contents of the bottles were titrated during $\sim 3$ min by means of an automated, precise titration system, with colorimetric end-point detection (Williams \& Jenkinson 1982). The precision achieved in replicates was CV $\sim 0.05 \%$.

\subsection{Sediment traps}

Free-floating sediment traps were deployed below the 1\% surface PAR level (50 m depth in D1 and $100 \mathrm{~m}$ depth in the rest), well below the surface mixed layer. The traps were recovered $24 \mathrm{~h}$ after deployment, together with the incubation bottles for metabolic experiments. The trap array consisted of 12 tubular traps placed in an Xframe, similar to the model described by Knauer et al. (1979). Each trap had a nominal surface area of $0.00312 \mathrm{~m}^{2}$. After recovery, the contents of the traps were filtered through Whatman GF/F fibre-filters for measurements of POC and PON concentrations as described above. Swimmers entering the traps were removed from filters under a binocular microscope. No poison was used due to the short-time deployment. In fact, no statistical differences were observed among POC/PON ratios in the water column and sediment traps, giving evidence that remineralization processes inside the traps were minimal.

\section{Results}

\subsection{Water column structure, nutrient salts and organic matter}

T-S diagrams from the 4 stations (Fig. 2) reflect the progressive warming of upwelled surface waters and the mixing with saltier non-upwelled waters along the offshore path of the filament. For comparative purposes, the T-S plot of an oceanic station sampled during the cruise is depicted. In spite of the surface variability along the filament, the coastal waters transported by the filament are clearly identified by colder temperatures and lower salinities. 
Station D1, the closest to shore of the 4 stations, presented low surface temperatures $\left(<19^{\circ} \mathrm{C}\right)$ and salinities less than 36.3 in the upper $10 \mathrm{~m}$ and below $60 \mathrm{~m}$, an indication that upwelled water was being advected offshore over denser non-upwelled sub-surface waters (Fig. 3). The temperature dropped smoothly from surface to depth, showing weak stratification, which allowed the presence of measurable concentrations of inorganic nutrients in the euphotic zone (Fig.4). Farther off the shelf, the surface, already modified, upwelled water with higher salinity ( $>36.5$ ) than the shelf waters, was warmed by solar heating $\left(>22.5^{\circ} \mathrm{C}\right)$, inducing the development of a sharp thermocline near $20 \mathrm{~m}$, as observed from station D2 to D4 (Fig.3). The three outer stations were separated at roughly $60 \mathrm{~km}$ intervals along filament F1. From the estimated and observed velocities along filament, which ranged between 0.2 and $0.6 \mathrm{~m} \mathrm{~s}^{-1}$ (Barton et al., 2004), water parcels would take 1-3 days to travel between station pairs. This implies 10-20 days to re-circulate completely around C7 back to the shelf.

Near-surface nutrient concentrations dropped significantly offshore (e.g. from $\sim 1 \mu \mathrm{M}$ $\mathrm{NO}_{3}{ }^{-}$at $15 \mathrm{~m}$ in $\mathrm{D} 1$ to $0.1 \mu \mathrm{M}$ in $\mathrm{D} 3$ and $0.05 \mu \mathrm{M}$ in D4), although effective nitrate utilization by phytoplankton was apparent near the surface at all stations (Fig.4). Indeed, whereas phosphate and silicate presented measurable concentrations up to the surface, nitrate was almost undetectable in the upper $10 \mathrm{~m}$ of D1 and in the upper $20 \mathrm{~m}$ of D3 and D4. The regression of nitrate versus phosphate for 0- $100 \mathrm{~m}$, yields a slope of 20.0 ( \pm 0.7$)$, well over the Redfield ratio for marine plankton (Anderson, 1995). However, this potential excess of nitrate relative to phosphate was only available below the mixed layer, where phytoplankton could not make use of it. The intercept of the regression (Fig.5) shows that at zero nitrate there is still some excess phosphate available, suggesting that nitrate was the main limiting nutrient for phytoplankton even in the most coastal waters. A similar pattern applied for silicate, which showed surface concentrations of $>0.5 \mu \mathrm{M}$ in all the stations at near zero values of nitrate (Fig. 5). Silicate is necessary for diatom growth and hence is expected to be depleted only by dense diatom blooms, a situation which did not occur. Below $60 \mathrm{~m}$, silicate increased more sharply than nitrate, suggesting a dominance of silica dissolution over organic matter remineralization.

At the three stations where nutrients were analysed, a nitrite maximum was found in the upper layers of the thermocline $(20-40 \mathrm{~m})$. Nitrite peaks ranged from $0.15 \mu \mathrm{M} \mathrm{NO}_{2}{ }^{-}$at 
$\mathrm{D} 3$ to $0.6 \mu \mathrm{M}$ at D4. Nitrite maxima at the thermocline level have been documented from other coastal and oceanic regions and are attributed either to nitrification of ammonia excreted by zooplankton and micro-organisms (e.g. Collos \& Slawyk, 1983) or from reduction of nitrate by phytoplankton (Wada \& Hattori, 1991).

Particulate organic material (POM) decreased at the surface from station D1 to D4, showing a trend opposite to light transmission (Figs. 3 and 6). However, water-column integrated values of the different POM proxies (POC, PON, Proteins and Chl) reflected different transitional patterns (Table I). Whereas integrated POC and PON did not show a clear decrease towards offshore stations, integrated Proteins (Pt) and Chl were significantly higher at the two most coastal stations. Since Pt and Chl are proxies of living material, their higher concentrations near the coast may be caused by a higher abundance of large phytoplankters (see below). Indeed, assuming a C/Chl ratio of 50 (see Methods), the contribution of phytoplankton carbon to total POC decreased from $53 \%$ at D1 to $27 \%$ at D4 (Table II). Nevertheless, some of this apparent decrease in the phytoplankton contribution to total POC could be caused by an offshore increase in the C/Chl ratio.

At D1, where particulate matter was concentrated in the upper $15 \mathrm{~m}$, the depth of the euphotic zone (down to 1\% PAR) was restricted to the upper $25 \mathrm{~m}$, due to enhanced light attenuation by phytoplankton and other particulate material (Fig. 3). The chlorophyll maximum (CM) decreased in magnitude while deepening down to 30-50 m in the water column. A thicker, but smaller in magnitude, CM was observed at D3, where the two filament branches merged. The euphotic zone deepened to $75-85 \mathrm{~m}$ at stations D2 to D4. Peaks in Chl, Pt and POM were 3 to 5 fold higher at D1 than at the other three stations.

Carbon to nitrogen ratios $(\mathrm{C} / \mathrm{N})$ in POM from the water column (mean $=6.8 \pm 1.5, \mathrm{n}=$ 31 ) were close to the Redfield ratio with the highest values $(8.6 \pm 1.2)$ at D1 and the lowest $(5.7 \pm 1.4)$ at $\mathrm{D} 4$. These values did not differ from the ratios found in more oceanic waters during the same cruise (mean value for the whole cruise $=6.7 \pm 2.3, \mathrm{n}=$ 406). However, they are significantly lower than the ratios observed in the same region during early autumn (mean $=12.5 \pm 2.7$; Arístegui, unpub.). This indicates first that, compared to autumn, the organic matter in summer time was more labile, and second 
that there were no appreciable differences between the lability of the organic matter transported by the filament and that of the surrounding waters.

Dissolved organic carbon (DOC) presented the lowest integrated concentrations at D1 and the highest at D2. The vertical profiles (Fig. 6) show DOC values as low as $60 \mu \mathrm{M}$ in the recently upwelled, low salinity $(<36.35)$ waters of D1. On the contrary, values $>100 \mu \mathrm{M}$ were observed in subsurface and saltier (>36.4) waters of D1 and in the upper $20 \mathrm{~m}$ of D3. D2 and D4 presented the most homogeneous profiles, although DOC in D2 was about $20 \mu \mathrm{M}$ in excess at all depths compared to D4, suggesting an offshore utilization of DOC along the filament path.

\subsection{Changes in plankton community structure and biomass}

The vertical distributions in the abundance of heterotrophic bacteria (HB), phytoplankton, and protozoa are shown for the 4 stations in Figures 7 to 9. HB presented higher abundances in the upper $50 \mathrm{~m}$ of all the stations, decreasing with depth (Fig. 7). Integrated values in the water column were two-fold smaller at D1 with respect to the other stations (Table III). Only at this station did High DNA bacteria prevail over the Low DNA populations (Fig. 7). Whether H-DNA bacteria reflect populations of “more actively respiring” or simply "more healthy” (not nutrient-limited) bacteria cells is not clear. It seems however, that the relative increase in H-DNA bacteria was not a consequence of a lower grazing pressure on these populations, since the abundance of their potential grazers (NHF and ciliates) was no smaller than at the other stations (Fig.7).

The different phytoplankton groups showed variable and complex distributions. Large phytoplankters were more abundant at the two more coastal stations (D1 and D2; Fig. 8). Integrated diatom abundances were similar at D1 and D2 (Table III), but at D1 they were mainly concentrated at the surface. Dinoflagellates, on the contrary, were more abundant at D2, showing the lowest abundances at D4. Both ANF and PE presented the highest integrated abundances at stations D2 and D4, although displaying different vertical distributions (Figs. 8, 9). At D2, PE peaked at 70-90 m, well below the CM, while ANF were more abundant at the CM level (50 m). At D4, both PE and NAF peaked at $30 \mathrm{~m}$, in the upper range of the CM. Synechococcus (Syn) and 
Prochlorococcus (Proc) type cyanobacteria showed an opposite distribution pattern to large phytoplankton, increasing towards more oceanic waters.

In terms of biomass, the nano- and pico-heterotrophs $\left(\mathrm{POC}_{\mathrm{H}<10 \mu}=\mathrm{POC}_{\mathrm{NHF}}+\mathrm{POC}_{\mathrm{HB}}\right)$ were as abundant as the nano- and pico-phytoplankton $\left(\mathrm{POC}_{\mathrm{A}<10 \mu}=\mathrm{POC}_{\mathrm{NAF}}+\mathrm{POC}_{\mathrm{PE}}+\right.$ $\mathrm{POC}_{S y n}+\mathrm{POC}_{\text {Proc }}$, except at station D1, where the low abundance of picophytoplankton led to a $\mathrm{POC}_{\mathrm{A}<10 \mu} / \mathrm{POC}_{\mathrm{H}<10 \mu}$ ratio of 0.6 (Table II). Indeed, autotrophs $<10 \mu$ contributed only $14 \%$ at D1 to the total autotrophic biomass, increasing to $79 \%$ at D4, as result of a shift from larger to smaller phytoplankton cells along the coastal offshore gradient.

\subsection{Plankton metabolism and vertical carbon fluxes}

Figure 3 illustrates the vertical profiles of gross primary production $\left(\mathrm{P}_{\mathrm{g}}\right)$, net community production $\left(P_{n}\right)$, and dark community respiration $\left(R_{d}\right)$. $P_{n}$ was positive only in the 10-30 m depth-range over the CM peak, except at D3, where $P_{n}$ was negative through the whole water column and the CM had the lowest magnitude. The positive $\mathrm{P}_{\mathrm{n}}$ values over the CM layer in the other stations were due to an increase in the photosynthetic activity of phytoplankton at each station rather to a decrease in the $\mathrm{R}_{\mathrm{d}}$ rates, as observed from the vertical profiles. Euphotic zone integrated $R_{d}$ decreased offshore, ranging from 135 mmol $\mathrm{O}_{2} \mathrm{~m}^{-2} \mathrm{~d}^{-1}$ at D1 to $51 \mathrm{mmol} \mathrm{O}_{2} \mathrm{~m}^{-2} \mathrm{~d}^{-1}$ at D4 (Fig. 10). This decrease was, however, not matched by a similar gradient either in POC or in DOC. Integrated $\mathrm{P}_{\mathrm{n}}$ rates in the water column were highest ( $>10$ fold) at $D 4$, due to the lower $R_{d}$ rates, which led to positive $\mathrm{P}_{\mathrm{n}}$ values in the whole euphotic zone. Stations D1 and D2 presented an almost metabolically balanced (i.e. $\mathrm{P}_{\mathrm{n}}$ close to zero) euphotic zone, whereas D3 was in a clear metabolic imbalance $\left(\mathrm{P}_{\mathrm{n}}=-45 \mathrm{mmol} \mathrm{O}_{2} \mathrm{~m}^{-2} \mathrm{~d}^{-1}\right)$.

The vertical POC fluxes estimated from drifting sediment traps deployed at $50 \mathrm{~m}$ at D1 and $100 \mathrm{~m}$ at D2-D4 were relatively low (Table IV). The highest average flux (16.8 \pm $\left.2.7 \mathrm{mmol} \mathrm{C} \mathrm{m}^{-2} \mathrm{~d}^{-1} ; \mathrm{n}=6\right)$ was obtained at D1, and the lowest at D2 $(6.4 \pm 1.9 ; n=5)$. Stations D3 (9.4 $\pm 1.8 ; \mathrm{n}=8)$ and D4 (8.4 $\pm 1.5 ; \mathrm{n}=9)$ recorded similar fluxes. Assuming a photosynthetic quotient (PQ) of 1.2, and a respiratory quotient (RQ) of 0.8 (Robinson and Williams, 1999), the proportion of organic carbon collected with the 
traps, related to $\mathrm{P}_{\mathrm{g}}$ (expressed in carbon terms), ranged from 6\% (in D2) to 19\% (in D3) (Table IV).

\section{Discussion}

The filament studied was revealed as a complex and highly variable system in terms of hydrological structure, plankton distribution and carbon-associated fluxes. Some of the offshore filament waters were re-circulated back to the near-shore zone, advected by the cyclonic rotation of the recurrent eddy located in the trough between the eastern islands and the African shelf. The surface-water recirculation was evident in SST and ocean colour images (Fig. 1b), but the temperature maps also gave indication of entrainment of colder filament waters by a warmer anticylonic eddy developing south of Gran Canaria at the end of the cruise (Barton et al., 2004).

Compared to a similar study off Cape Juby carried out in August 1993 (Barton et al., 1998), surface temperatures in the shelf stations were about $0.5-1^{\circ} \mathrm{C}$ higher in 1999 . During our cruise, winds were upwelling-favourable, but less intense and constant than during the 1993 survey (Barton et al., 2003). This might have led to weaker upwelling, as evidenced by nitrate exhaustion in the upper 5-10 m even at the most coastal stations of the cruise (data not shown). However, integrated Chl values on the shelf were similar in both studies, suggesting that nutrient differences were not significantly important in controlling the magnitude of the phytoplankton biomass.

The four stations selected for metabolic studies along the filament, portrayed rather well the complexity of the filament structure. The shelf-break station (D1) presented clear evidence of recently upwelled water. Cold and fresh water in the upper15 m overlaid saltier non-upwelled water. Phytoplankton (mainly large diatoms and dinoflagellates) concentrated at the surface, contributing about half of the particulate organic matter. Picophytoplankton (Syn and Proc) and heterotrophic bacteria (HB) presented low abundances compared to more offshore waters. DOC was also low in the surface upwelled waters, with values $(60 \mu \mathrm{M})$ characteristic of thermocline layers (Arístegui et. al., 2003), but doubled its concentration $(>120 \mu \mathrm{M})$ in the underlying saltier subsurface water, supporting the evidence of advection of upwelled water over denser nonupwelled water. 
A marked change in plankton community structure occurred between stations D1 to D2 (the first true filament station). In the latter station, diatoms and, particularly, dinoflagellates were still abundant, but the contribution of small phytoplankton to total autototrophic biomass increased from 14\% in D1 to 65\%, while the biomass of micro heterotrophic organisms doubled compared to D1. In spite of the sharp change in phytoplankton size structure, there is no evidence of mass sedimentation of diatoms on shelf waters. It seems more plausible that large phytoplankton were grazed by mesozooplankton near the coast. In a previous study of the Cape Juby filament, HernándezLeón et al. (2002) observed that meso-zooplankton almost fulfil their metabolic demands with phytoplankton on the shelf, but consumed up to a 85\% of non-pigmented food along the offshore path of the filament. Studies on the impact of micro- and mesozooplankton in a filament off the NW Iberian upwelling system reached the same conclusion about the fate of the diatom bloom (Fileman and Burkill, 2001; Halvorsen et al., 2001).

Autotrophic POC $\left(\mathrm{POC}_{\mathrm{Chl}}\right)$ contributed the bulk of living POC and decreased gradually from the coast to the open ocean, following a trend roughly inverse to the contribution of $\mathrm{POC}_{\mathrm{A}<10 \mu}$ to $\mathrm{POC}_{\mathrm{Chl}}$. This decreasing pattern was observed neither in DOC nor in POC, both of which showed their highest values in D2 and D3. DOC did not correlate with primary production or with phytoplankton biomass, since it probably depended more on microbial loop processes than on direct exudation by phytoplankton, as occurs in other upwelling regions (e.g. Barbosa et al., 2001). Average POC and DOC concentrations in the euphotic zone of these two stations were about 1.5-2 times higher than average values in more oceanic waters of the Canary Islands region (Arístegui et al., 2003). Furthermore, DOC was about 1.5 times higher than reported in other studies from upwelling filaments in the NE Atlantic (Olli et al., 2001; García-Muñoz et al. 2004). Since station D3 showed among the lowest values of living organic carbon, the distribution of POC and DOC probably responded to passive accumulation of detritus, re-circulated by the eddy.

There were, however, appreciable differences in plankton community structure and metabolism between stations D2 and D3. The former presented a considerably higher 
biomass of autotrophic organisms, particularly of eukaryotic forms, and an almost balanced euphotic zone metabolism ( $\mathrm{P}_{\mathrm{n}}$ close to zero). On the contrary, D3 -the station where the two filament branches merged- presented a much lower autotrophic biomass and a net metabolic imbalance $\left(\mathrm{P}_{\mathrm{n}}<0\right)$. At D4 - the most offshore station- POC and DOC were lower than at $\mathrm{D} 3$, but proteins and $\mathrm{POC}_{\mathrm{A}<10 \mu}$ increased. This station presented the highest $P_{n}$ and the lower $R_{d}$ rates of the four stations studied. Its position in the frontal region between the filament and oceanic waters coincided with the wind and current shearing area at the eastern Gran Canaria coast. Previous studies in these frontal regions have shown that primary production is greatly enhanced with respect to ambient waters (Arístegui et al., 1989; Basterretxea et al., 2002); this would explain the increases in gross and net production compared with station D3.

The examination of plankton metabolism in the euphotic zone of all the stations in relation with $\mathrm{POC}$ sedimentation rates $\left(\mathrm{POC}_{\text {sed }}\right)$ suggests that horizontal transport and surface mineralization of organic matter prevailed over vertical fluxes along the filament (Table IV). $\mathrm{R}_{\mathrm{d}}$ was 5 to 16 times higher than $\mathrm{POC}_{\text {sed, }}$, the ratio being highest in the filament root (D2) and lowest at the offshore-most station (D4). Comparing with two other case studies on filaments from the Northeast Atlantic (Cape Guir, Head et al. 1996; Arístegui \& Harrison, 2002; and NW Iberia, Olli et al., 2001), the Cape Juby filament presented the lowest $\mathrm{POC}_{\text {sed }}$ with respect to primary production (Table IV). The NW Iberia filament (Leg 1, August 1998) was sampled after intense wind-driven upwelling. The filament was characterized by similar POC, but lower DOC concentrations (Alvárez-Salgado et al., 2001) and lower micro-heterotrophic biomass (Barbosa et al., 2001; Fileman \& Burkill, 2001) than the Cape Juby filament, suggesting that during our study microbial loop processes were more relevant. This would explain the high respiration rates observed along the Cape Juby filament. The Cape Guir filament (September 1992) presented similar $\mathrm{R}_{\mathrm{d}}$ rates, about two fold higher integrated POC values and $\mathrm{P}_{\mathrm{g}}$ (Fig. 10; Arístegui \& Harrison, 2002), but lower HB biomass (Head et al., 1996) than Cape Juby (Table IV). Moreover, the Cape Guir filament showed a positive $P_{n}$ at all stations, while, overall, $P_{n}$ was close to zero in Cape Juby (Fig. 10). Since part of the non-sedimented $\mathrm{P}_{\mathrm{g}}$ is presumably lost by grazing, the only way to explain the high $R_{d}$ and the null $P_{n}$ is by advective return of organic matter in surface waters. 
New production would be mostly generated and accumulated in the closer-to-shore waters of the African shelf (Fig. 1b), where microbial respiration would be lower. Part of this production is eventually transported offshore by filaments. However, wind relaxation and eddy circulation may decrease the organic matter transport by enhancing remineralization processes, leading to a transient metabolic imbalance in surface waters as observed throughout our experiment. Indeed, during our study, a large fraction of the coastally produced organic matter was respired while being exported along the Cape Juby filament. The mineralization of organic matter was presumably enhanced by the retention mechanism of the filament, caused by the cyclonic circulation of the offshore eddy. Thus, in terms of oceanic export of coastal upwelled water, the Cape Juby filament (at least during the study) would be less efficient than other filaments where water recirculation is less pronounced. Several in situ studies (e.g. Basterretxea \& Arístegui, 2000) and satellite images (Arístegui et al., 1997; Pacheco \& HernándezGuerra, 1999) have shown that the Cape Juby filament may at times exchange water and biological properties with island eddies, as occurred at the end of the present cruise. If the exchange occurs during an episode of intense filament export, large amounts of particulate organic matter may be exported to the open ocean, as observed on other occasions (Arístegui \& Montero, 2004). Otherwise (as in the present study), a large fraction of living particulate organic matter would be readily mineralized before being exchanged to the open ocean. It is, therefore, the variability in the eddy-filament interactions that governs the coastal-open ocean export in the Cape Juby region, unlike other coastal upwelling regions where the presence of offshore eddies is not so frequent.

\section{Acknowledgements}

This work has been supported through the European Union (project CANIGO, MAS3.CT96-0060) and the Spanish government (project COCA, REN2000-U471CO2-02-MAR). We thank the officers and crew of the BIO Hespérides, as well as the staff of the UTM (CSIC) for their invaluable help at sea. Alonso Hernández-Guerra kindly provided the SeaWiFS image.

\section{References}

Álvarez-Salgado, X.A., Doval, M.D., Borges, A.V., Joint, I., Frankinouglle, M., Woodward, E.M.S., \& Figueiras, F.G. (2001). Off-shelf fluxes of labile materials by an upwelling filament off the NW Iberian upwelling system. Progress in Oceanography, 51, 321-339. 
Anderson, L.A. (1995). On the hydrogen and oxygen content of marine phytoplankton. Deep-Sea Research I, 42, 1675-1680

Arístegui, J., \& Harrison, W.G. (2002) Decoupling of primary production and community respiration in the ocean: implications for regional carbon studies. Aquatic Microbial Ecology, 29,199-209

Arístegui, J, \& Montero, M.F. (2004). Temporal and spatial changes in microplankton respiration and biomass in the Canary Islands: the effect of mesoscale variability. Journal of Marine Systems (in press)

Arístegui, J., Hernández-León, S., Gómez, M., Medina., L., Ojeda, A., \& Torres, S. (1989). Influence of the north trade winds on the biomass and production of neritic plankton in Gran Canaria. Scientia Marina, 53, 223-229.

Arístegui, J., Tett, P., Hernández-Guerra, A., Basterretxea, G., Montero, M.F., Wild, K., Sangrà, P., Hernández-León, S., Cantón, M., García-Braun, J.A., Pacheco, M., \& Barton, E.D. (1997). The influence of island-generated eddies on chlorophyll distribution: a study of mesoscale variation around Gran Canaria. Deep-Sea Research I, 44, 71-96

Arístegui, J., Barton, E.D., Montero, M.F. García-Muñoz, M. \& Escánez, J. (2003). Organic carbon distribution and water-column respiration in the NW AfricaCanaries CTZ region. Aquatic Microbial Ecology, 33, 289-301.

Barbosa, A.B., Galvao, H.M., Mendes, P.A., Älvarez-Salgado, X.A., Figueiras, F.G., \& Joint, I. (2001). Short-term variability of heterotrophic bacterioplankton during upwelling off the NW Iberian margin. Progress in Oceanography, 51, 339-359.

Barton, E.D., Arístegui, J., Tett, P.,.Cantón, M., García-Braun, J., Hernández-León, S., Nykjaer, L., Almeida, C., Almunia, J., Ballesteros, S., Basterretxea, G., Escánez, J., García-Weill, L., Hernández-Guerra, A., López-Laatzen, F., Molina, R., Montero, M.F., Navarro-Pérez, E., Rodríguez, J.M., van Lenning, K., Vélez, H., \& Wild, K. (1998). The transition zone of the Canary Current upwelling region. Progress in Oceanography, 41, 455-504

Barton, E.D., Arístegui, J., Tett, \& Navarro-Pérez, E., (2004). Variability in the Canary Islands area of filament-eddy exchanges. Progress in Oceanography (this volume) Basterretxea, G., \& Arístegui, J. (2000). Mesoscale variability in phytoplankton biomass distribution and photosynthetic parameters in the Canary-NW African coastal transition zone. Marine Ecology Progress Series, 197, 27-40 
Basterretxea, G., Barton, E.D., Tett, P., Sangrá, P., Navarro-Pérez, E., \& Arístegui, J. (2002). Eddy and DCM response to wind shear in the lee of Gran Canaria. Deep-Sea Research I, 49, 1087-1101.

Bode, A., Barquero, S., Varela, M., Braun, J.A., \& de Armas, D. (2001). Pelagic bacteria and phytoplankton in oceanic waters near the Canary Islands in summer. Marine Ecology Progress Series, 209, 1-17.

Borsheim, K.Y., \& Bratbak, G. (1987). Cell volume to cell carbon conversion factors for a bacterivorous Monas sp. enriched from seawater. Marine Ecology Progress Series, 36, 171-175.

Brink, K., \& Cowles, T. (1991). The coastal transition zone experiment. Journal of Geophysical Research, 96, 14637-14647.

Bryan, J.R., Riley, J.P., \& Williams, P.J. leB. (1976). A procedure for making precise measurements of oxygen concentration for productivity and related studies. Journal of Experimental Marine Biology and Ecology, 21, 191-197

Buck, K.R., Chavez, F.P., Campbell, L. (1996). Basin-wide distributions of living carbon components and the inverted trophic pyramid of the central gyre of the North Atlantic Oceans, summer 1993. Aquatic Microbial Ecology, 10, 283-298.

Campbell, L., Liu, H., Nolla, H.A., \& Vaulot D. (1997). Annual variability of phytoplankton and bacteria in the subtropical North Pacific Ocean at Station ALOHA during the 1991-1994 ENSO event. Deep Sea Research I, 44, 167-192.

Carrit, D.E., \& Carpenter, J.H. (1966). Comparison and evaluation of currently deployed modifications of the Winkler method for determining dissolved oxygen in seawater: a NASCO Report. Journal of Marine Research, 24, 287-318.

Cho, B.C., \& Azam, F. (1990). Biogeochemical significance of bacterial biomass in the ocean’s euphotic zone. Marine Ecology Progress Series, 63, 253-259.

Christian, J.R., \& Karl, D.M. (1994). Microbial community structure at the U.S.-Joint Global Ocean Flux Study Station ALOHA: Inverse methods for estimating biochemical indicator ratios. Journal of Geophysical Research, 99, 14269-14276.

Collos, Y., \& Slawyk, G. (1983). Ammonium and nitrate in the tropical and equatorial Atlantic: relations with the primary nitrite maximum. Marine Biology Letters, 4, 295-308. 
Fileman, E., \& Burkill, P. (2001). The herbivorous impact of microzooplankton during two short-term Lagrangian experiments off the NW coast of Galicia in summer 1998. Progress in Oceanography, 51,361-383.

García-Muñoz, M., Arístegui, J., Pelegrí, J.L., Antoranz, A., Ojeda, A., \& Torres, M. (2004). Exchange of carbon by an upwelling filament off Cape Guir (NW Africa). Journal of Marine Systems (in press)

Gasol, J.M., del Giorgio, P.A., \& Duarte, C.M. (1997). Biomass distribution in marine planktonic communities. Limnology and Oceanography, 42, 1353-1363.

Gasol, J.M., Zweifel, U.L., Peters, F., Fuhrman, J.A. \& Hagstrom, A. (1999).

Significance of size and nucleic acid content heterogeneity as measured by flow cytometry in natural planktonic bacteria. Applied Environmental Microbiology, 65, 4475-4483.

Grasshoff, K., Ehrhardt, M., \& Kremling, K.(1983). Methods of Seawater Analysis. Deerfield Beach, FL: Verlag Chemie.

Haas, L.W. (1982). Improved epifluorescence microscopy for observing planktonic micro-organisms. Annales de l’Institut Oceanographique, Paris, 58 (S), 261-266.

Halvorsen, E., Hirst, A.G., Batten, S.D., Tande, K.S., \& Lampitt, R.S. (2001). Diet and community grazing by copepods in an upwelled filament off the NW coast of Spain. Progress in Oceanography, 51, 399-421.

Head, E.J.H., Harrison, W.G., Irwin, B.I., Horne, E.P.W., \& Li, W.K.W. (1996). Plankton dynamics and carbon flux in an area of upwelling off the coast of Morocco. Deep-Sea Research I, 43, 1713-1738.

Hernández-León, S., Almeida, C., Portillo-Hahnefeld, A., Gómez, M., Rodríguez, J.M., \& Arístegui, J. (2002). Zoopankton biomass and indices of feeding and metabolism in relation to an upwelling filament off northwest Africa. Journal of Marine Research, 60, 327-346.

Hewes, C.D., Sakshaug, E., Reid, F.M.H., \& Holm-Hansen, O. (1990). Microbial autotrophs and heterotroph eukaryotes in Antarctic waters: Relationships between biomass and chlorophyll, adenosine triphosphate and particulate organic carbon. Marine Ecology Progress Series, 63, 27-35.

Holm-Hansen, O., Lorenzen, C.J., Holmes, R.W., \& Strickland, J.D.H. (1965). Fluorometric determination of chlorophyll. Journal du Conseil, 30, 3-15. 
Joint, I., Inall, M., Torres, R., Figueiras, F.G., Álvarez-Salgado, X.A., Rees, A.P., \& Woodward, E.M.S. (2001). Two lagrangian experiments in the Iberian upwelling system: tracking an upwelling event and an off-shore filament. Progress in Oceanography, 51, 221-248.

Kana, T., \& Glibert, P.M. (1987). Effects of irradiances up to $2000 \mu \mathrm{mEm}^{-2} \mathrm{~s}^{-1}$ on marine Synechococcus WH 7803-I. Growth, pigmentation, and cell composition. Deep-Sea Research I, 34, 479-516.

Knauer, G.A., Martin J.H., \& Bruland, K.W. (1979). Fluxes of particulate carbon, nitrogen and phosphorous in the upper water column of the northeast Pacific. DeepSea Research I, 26, 97-108.

Lee, S., \& Fuhrman, J.A. (1987). Relationships between biovolume and biomass of naturally derived marine bacterioplankton. Applied Environmental Microbiology, 53, 1298-1303.

Li, W.K.W., Dickie, P.M., Irwin, B.D., \& Wood, A.M. (1992). Biomass of bacteria, cyanobacteria, prochlorophytes and photosynthetic eukaryotes in the Sargasso Sea. Deep-Sea Research I, 39, 501-519.

Lowry, P.H., Rosenbrough, N.J., Farr, A.L., \& Randall, R.J. (1951). Protein measurement with a Folin phenol reagent. Journal of Biological Chemistry, 193, 265-275.

Nagata, T. (2000). Production mechanims of dissolved organic matter. In D.L.Kirchman (Ed.), Microbial ecology of the oceans (pp. 121-152). New York: Wiley and Sons.

Olli, K., Riser, C.W., Wassmann, P., Ratkova, T., Arashkevich, E., Pasternak, A. (2001). Vertical flux of biogenic matter during a Lagrangian study off the NW Spanish continental margin. Progress in Oceanography, 51, 443-466.

Pacheco, M.M., Hernández-Guerra, A. (1999). Seasonal variability of recurrent phytoplankton pigment patterns in the Canary Islands area. International Journal of Remote Sensing, 20, 1404-1418.

Peterson, G.L. (1983). Determinations of total protein. In Methods of enzymology, 91 (pp. 95-119). Academic Press.

Robinson, C., \& Williams, P.J.leB. (1999). Plankton net community production and dark respiration in the Arabian Sea during September 1994. Deep-Sea Research II, 46, 745-765. 
Sharp, J., \& Peltzer, E. T. (1993). Procedures subgroup report. Marine Chemistry, 41, 37-49.

Sieracki, M.E., Haugen, E.M, \& Cucci, T.L. (1995). Overestimation of heterotrophic bacteria in the Sargasso Sea: direct evidence by flow and imaging cytometry. DeepSea Research I, 42, 1399-1409.

UNESCO (1994). Protocols for the Joint Global Ocean Flux Study (JGOFS) Core Measurement. Intergovernmental Oceanographic Commission, Manual and Guides 29,169 p.

Verity, P.G., Beatty, T.M., \& Williams, S.C. (1996). Visualization and quantification of plankton and detritus using digital confocal microscopy. Aquatic Microbial Ecology, 10, 55-67.

Wada, E., \& Hattori, A. (1991). Nitrogen in the Sea: Forms, Abundances and Rate Processes. Boca Ratón: CRC Press.

Welschmeyer, N.A., \& Lorenzen, C.J. (1984). Carbon-14 labelling of phytoplankton carbon and chlorophyll $a$ carbon: Determination of specific growth rates. Limnology and Oceanography, 29, 135-145.

Williams, P.J. leB., \& Jenkinson, N.W. (1982). A transportable microprocessorcontrolled precise Winkler titration suitable for field station and shipboard use. Limnology and Oceanography, 27, 576-584

Zubkov, M. V., Sleigh, M.A., \& Burkill, P.H. (2000). Assaying picoplankton distribution by flow cytometry of underway samples collected along a meridional transect across the Atlantic Ocean. Aquatic Microbial Ecology, 21, 13-20. 


\section{Legend of figures}

Figure 1. (a) Drift station positions D1-D4 overlaid on schematic of double filament structure. The two filaments F1 and F2 were associated with a series of cyclonic (C) and anticyclonic (A) eddies. The filament structure evolved significantly from a single filament F1 initially to the double structure depicted at the time of D4. Note the recirculation of filament waters around eddy C7. Water was advected along the filament at an average speed of $40 \mathrm{~km} \mathrm{~d}^{-1}$ (Barton et. al, 2004). (b) SeaWiFS image from 10 August, 1999, showing on-shore recirculation of high-chlorophyll water forced by eddy circulation.

Figure 2. Temperature $\left({ }^{\circ} \mathrm{C}\right)$ versus salinity (T-S) diagram for stations D1 to D4. The T-S plot of an oceanic station (27.52N, 16.93W) shows the strong salinity contrast between upwelled and oceanic waters.

Figure 3. Vertical profiles of potential temperature $\left(\mathrm{T},{ }^{\circ} \mathrm{C}\right)$, salinity $(\mathrm{S})$, light transmission ( $\mathrm{Tr}$, volts) and chlorophyll a (Chl, $\mathrm{mg} \mathrm{m}^{-3}$ ). Data on gross oxygen production $\left(\mathrm{P}_{\mathrm{g}}, \odot\right)$, net community production $\left(\mathrm{P}_{\mathrm{n}}, \mathrm{O}\right)$ and dark community respiration $\left(\mathrm{R}_{\mathrm{d}}, \mathbf{O}\right)$ are shown overlaid on the vertical profiles (all units in mmol $\mathrm{O}_{2} \mathrm{~m}^{-3} \mathrm{~d}^{-1}$ ). The vertical dashed line marks the boundary between positive and negative plankton metabolism values. The horizontal dashed line indicates the depth of the euphotic zone (assigned as the depth of the $1 \%$ of the surface photosynthetic active radiation, PAR)

Figure 4. Vertical profiles of inorganic dissolved nutrients (in $\mu \mathrm{M}$ ). Data on station D2 is lacking.

Figure 5. X-Y plots of nitrate versus phosphate, and nitrate versus silicate (all in $\mu \mathrm{M}$ ), from all stations.

Figure 6. Vertical profiles of dissolved organic carbon (DOC, $\mu \mathrm{M})$, particulate organic carbon (POC, $\mu \mathrm{M})$ and nitrogen (PON, $\mu \mathrm{M})$ and plankton proteins $\left(\mathrm{Pt}, \mathrm{mg} \mathrm{m}^{-3}\right.$ ).

Figure 7. Vertical distributions of plankton heterotrophic organisms (cells $\mathrm{ml}^{-1}$ )

Figure 8. Vertical distributions of micro- and nano-phytoplankton groups (cells $\mathrm{ml}^{-1}$ )

Figure 9. Vertical distributions of eukaryotic and prokaryotic pico-phytoplankton (cells $\mathrm{ml}^{-1}$ )

Figure 10. Variability in column-integrated values (all units in mmol $\mathrm{O}_{2} \mathrm{~m}^{-2} \mathrm{~d}^{-1}$ ) of gross oxygen production $\left(\mathrm{P}_{\mathrm{g}}\right)$, net community production $\left(\mathrm{P}_{\mathrm{n}}\right)$ and dark community respiration $\left(\mathrm{R}_{\mathrm{d}}\right)$. The ratios of $\mathrm{P}_{\mathrm{g}} / \mathrm{R}_{\mathrm{d}}$ are also shown. Data from the present study (Cape Juby; $27-28^{\circ} \mathrm{N}$ ) are compared with data from a previous study in another NW Africa upwelling filament (Cape Guir; $31^{\circ} \mathrm{N}$ ). As in the C. Juby study, metabolic experiments at the different C. Guir stations (A1 to C1) lasted 24 h. (data from C. Guir, modified from Arístegui and Harrison 2002) 
Table I. Integrated (0-50 m, D1; 0-100m, D2-D4) concentrations of particulate organic carbon (POC) and nitrogen (PON), dissolved organic carbon (DOC), proteins and chlorophyll a (Chl).

\begin{tabular}{lcccc}
\hline & D1 & D2 & D3 & D4 \\
\hline POC $\left(\mathrm{mmol} \mathrm{m}^{-2}\right)$ & 494 & 522 & 565 & 490 \\
PON $\left(\mathrm{mmol} \mathrm{m}^{-2}\right)$ & 58 & 86 & 88 & 76 \\
DOC $\left(\mathrm{mmol} \mathrm{m}^{-2}\right)$ & 4218 & 8147 & 7519 & 6432 \\
Proteins $\left(\mathrm{mg} \mathrm{m}^{-2}\right)$ & 8846 & 8737 & 6145 & 7770 \\
Chl $\left(\mathrm{mg} \mathrm{m}^{-2}\right)$ & 63 & 50 & 38 & 32 \\
\hline
\end{tabular}


Table II. Partition of organic carbon into autotrophic and heterotrophic components. Values (mg C m${ }^{-2}$ ) correspond to integrated (0-50 m, D1; 0-100m, D2-D4) concentrations. $\mathrm{POC}_{\text {total }}=$ total organic carbon; $\mathrm{POC}_{\mathrm{Chl}}=$ autotrophic organic carbon, estimated by converting chlorophyll to carbon, using a $\mathrm{C} / \mathrm{Chl}$ ratio $=50 ; \mathrm{POC}_{\mathrm{A}<10 \mu}=$ organic carbon of pico- and nano-autotrophs, derived from biomass conversion factors; $\mathrm{POC}_{\mathrm{H}<10 \mu}=$ organic carbon of pico- and nano-heterotrophs, derived from biomass conversion factors. See text for details on conversion factors.

\begin{tabular}{lcccc}
\hline & D1 & D2 & D3 & D4 \\
\hline POC $_{\text {total }}$ & 5928 & 6264 & 6780 & 5880 \\
POC $_{\text {Chl }}$ & 3150 & 2500 & 1900 & 1600 \\
POC $_{\mathrm{A}<10 \mu}$ & 466 & 1635 & 1076 & 1271 \\
POC $_{\mathrm{H}<10 \mu}$ & 760 & 1650 & 969 & 1430 \\
POC $_{\mathrm{Chl}}:$ POC $_{\text {total }}$ & 0.53 & 0.40 & 0.28 & 0.27 \\
POC $_{\mathrm{A}<10 \mu}:$ POC $_{\mathrm{Chl}}$ & 0.14 & 0.65 & 0.57 & 0.79 \\
POC $_{\mathrm{A}<10 \mu}:$ POC $_{\mathrm{H}<10 \mu}$ & 0.61 & 0.99 & 1.11 & 0.89 \\
\hline
\end{tabular}


Table III. Integrated (0-50 m, D1; 0-100m, D2-D4) densities (cells $\mathrm{cm}^{-2}$ ) of the different autotrophic and heterotrophic components of plankton studied. HB = heterotrophic bacteria; $\mathrm{HNF}=$ heterotrophic nanoflagellates; $\mathrm{ANF}=$ autotrophic nanoflagellates .

\begin{tabular}{lcccc}
\hline & D1 & D2 & D3 & D4 \\
\hline Heterotrophs & & & & \\
HB $\left(\times 10^{6}\right)$ & 25 & 64 & 47 & 43 \\
HNF $\left(\times 10^{4}\right)$ & 12 & 17 & 13 & 26 \\
Ciliates & 59 & 84 & 52 & 42 \\
Autotrophs & & & & \\
Prochlorococcus $\left(\times 10^{4}\right)$ & 6 & 250 & 210 & 230 \\
Synechococcus $\left(\times 10^{4}\right)$ & 14 & 160 & 290 & 130 \\
Picoeukaryotes $\left(\times 10^{3}\right)$ & 50 & 230 & 77 & 110 \\
ANF (x10 $)$ & 72 & 160 & 31 & 150 \\
Diatoms & 460 & 523 & 78 & 116 \\
Dinoflagellates & 419 & 762 & 476 & 307 \\
\hline
\end{tabular}




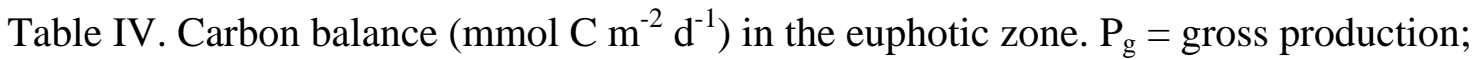
$\mathrm{R}_{\mathrm{d}}=$ dark community respiration; $\mathrm{POC}_{\text {sed }}=$ organic carbon collected with drifting sediment traps deployed below the euphotic zone. Data from the present study are compared with results from two other case studies of filaments from coastal upwelling systems in the Northeast Atlantic. Carbon balance $=\mathrm{P}_{\mathrm{g}}\left(\mathrm{R}_{\mathrm{d}}+\mathrm{POC}_{\mathrm{sed}}\right)$

\begin{tabular}{|c|c|c|c|c|c|c|}
\hline & \multicolumn{4}{|c|}{${ }^{1}$ Cape Juby } & \multirow{2}{*}{${ }^{2}$ Cape Guir } & \multirow{2}{*}{${ }^{3} \mathrm{NW}$ Iberia } \\
\hline & D1 & $\mathrm{D} 2$ & D3 & D4 & & \\
\hline \multicolumn{7}{|l|}{ Carbon gains: } \\
\hline$P_{g}$ & 113 & 100 & 47 & 91 & 79 to 217 & 70 to 88 \\
\hline \multicolumn{7}{|l|}{ Carbon losses: } \\
\hline$R_{d}$ & 108 & 97 & 84 & 41 & 50 to 65 & \\
\hline$P O C_{\text {sed }}$ & 17 & 6 & 9 & 8 & 24 to 26 & 8 to 20 \\
\hline$\% \mathrm{P}_{\mathrm{g}}$ sedimented & 15 & 6 & 19 & 9 & 12 to 30 & 14 to 26 \\
\hline Carbon balance & -12 & -3 & -46 & 42 & 29 to150 & \\
\hline
\end{tabular}

${ }^{1}$ Present study. ${ }^{2}$ Head et al. 1996; Arístegui and Harrison 2002. ${ }^{3}$ Olli et al. 2001 